\title{
Service Delivery: Focus on Dipaleseng Local Municipality: Mpumalanga
}

Commonwealth Journal of Local Governance

\author{
S'bonisile B. Zama \\ Human Sciences Research Council \\ PretoriaSouth, Africa 0002 \\ Email: szama@ hsrc.ac.za
}

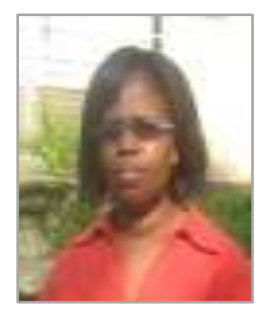

\begin{abstract}
The supply or lack of services impacts on people's quality of life, and so the Constitution of South Africa and other strategy documents emphasise the provision of services to all South African citizens irrespective of colour or creed. The services are vast and the responsibility for provision is divided between national, provincial and local authorities. This paper focuses on the delivery of services whose responsibility and accountability lies with the local municipalities, including: water; electricity; sanitation and refuse removal. The paper also explores the background to the recent unrest in the country with a focus on Dipaleseng Municipality, looking at its socio-economic situation, and challenges which include poverty, economic stability and provision of basic services. Sources of data include the South African media, journal articles, relevant documents, websites and databases.
\end{abstract}

Key words: poverty rate, GDP, unemployment, service delivery.

\section{Background}

South Africa has recently experienced protests and unrest due to dissatisfaction with service delivery.

Chief amongst the triggers of the unrest is lack of services including housing, sanitation, clean water, and electricity etc.

Figure 1 shows the locations of protests from 2007-2010, and Figure 2 the concerns of protestors (Jain, H. 2010: 31). As can be seen from Figure 2, amongst concerns that triggered the protests, housing is the top followed by water and electricity, sanitation etc. 
Figure 1: Location of protests in relation to housing services provision

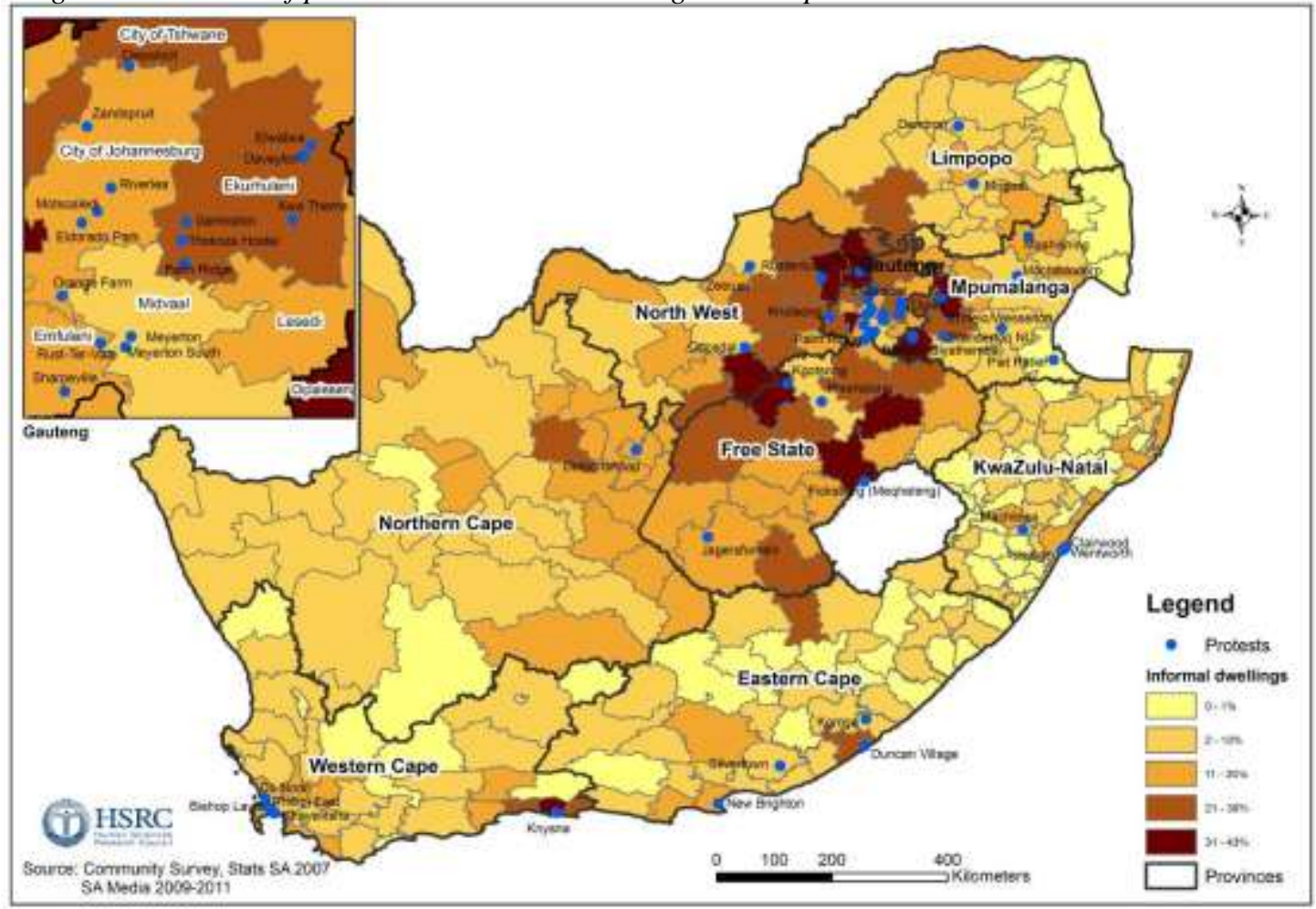

Figure 2: Concerns of protestors

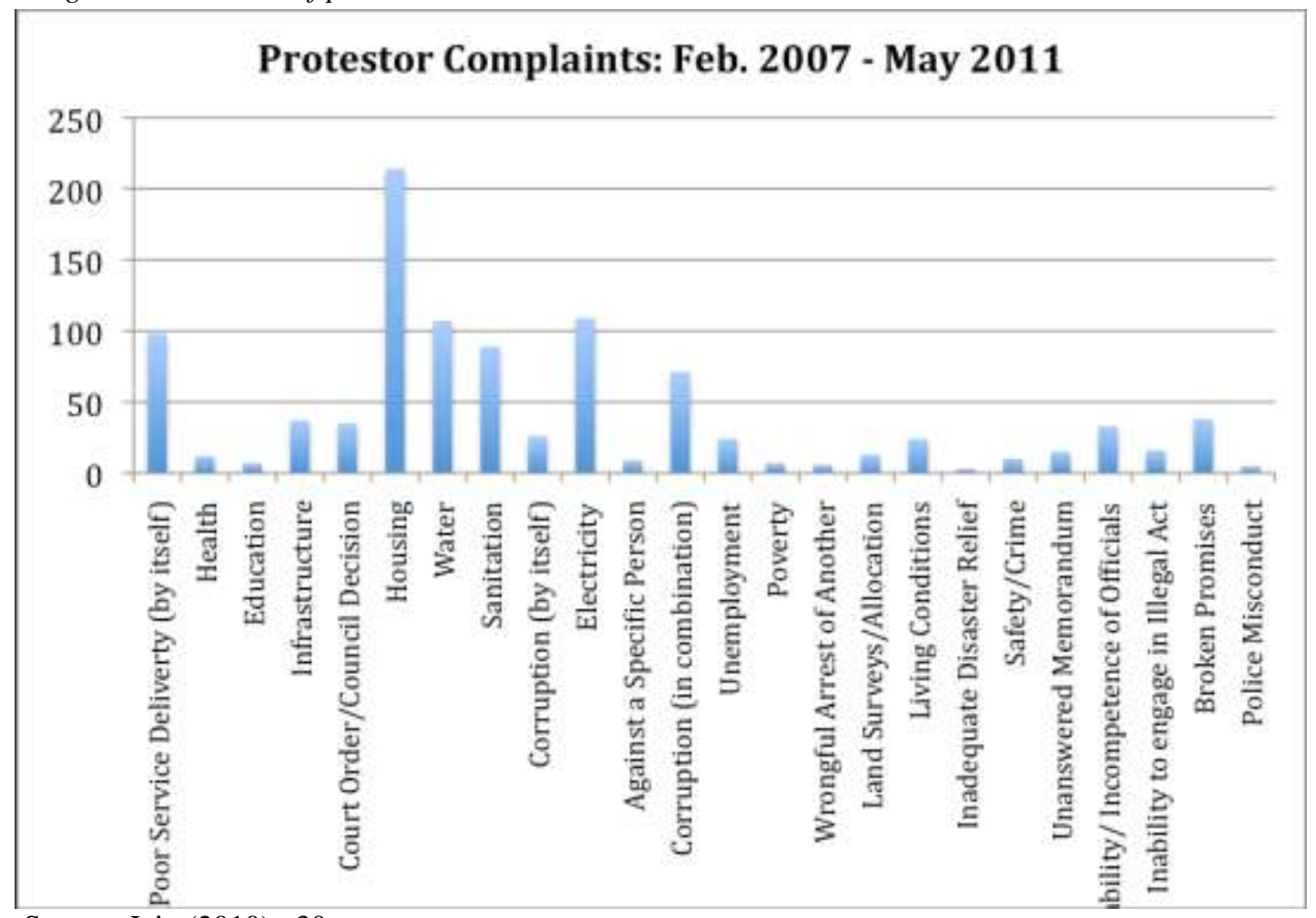

Source: Jain (2010) p30 
Housing is primarily the responsibility of the provincial department, but since people have direct contact with local authorities they tend to direct grievances about the backlog in housing at municipalities. For this reason housing and conditions in the informal settlements will also be briefly examined.

\section{Dipaleseng Municipality}

Dipaleseng Municipality is located in Mpumalanga Province and falls under Gert Sibande District Municipality. It covers an area of about $2619.4 \mathrm{~km}^{2}$ and has a population of 37,880 (Stats SA, 2007). The head office is situated in Balfour, one of the larger towns in the area. Other small towns include Dasville, Greylingstad, Grootvlei, Val and Willemsdal (Figure 3). Close to these towns are settlements, both urban and rural, but the municipality itself is largely rural. The townships and rural settlements include Siyathemba in Balfour, Nthorwane, Ekanini etc.

Figure 3: Dipaleseng Municipality

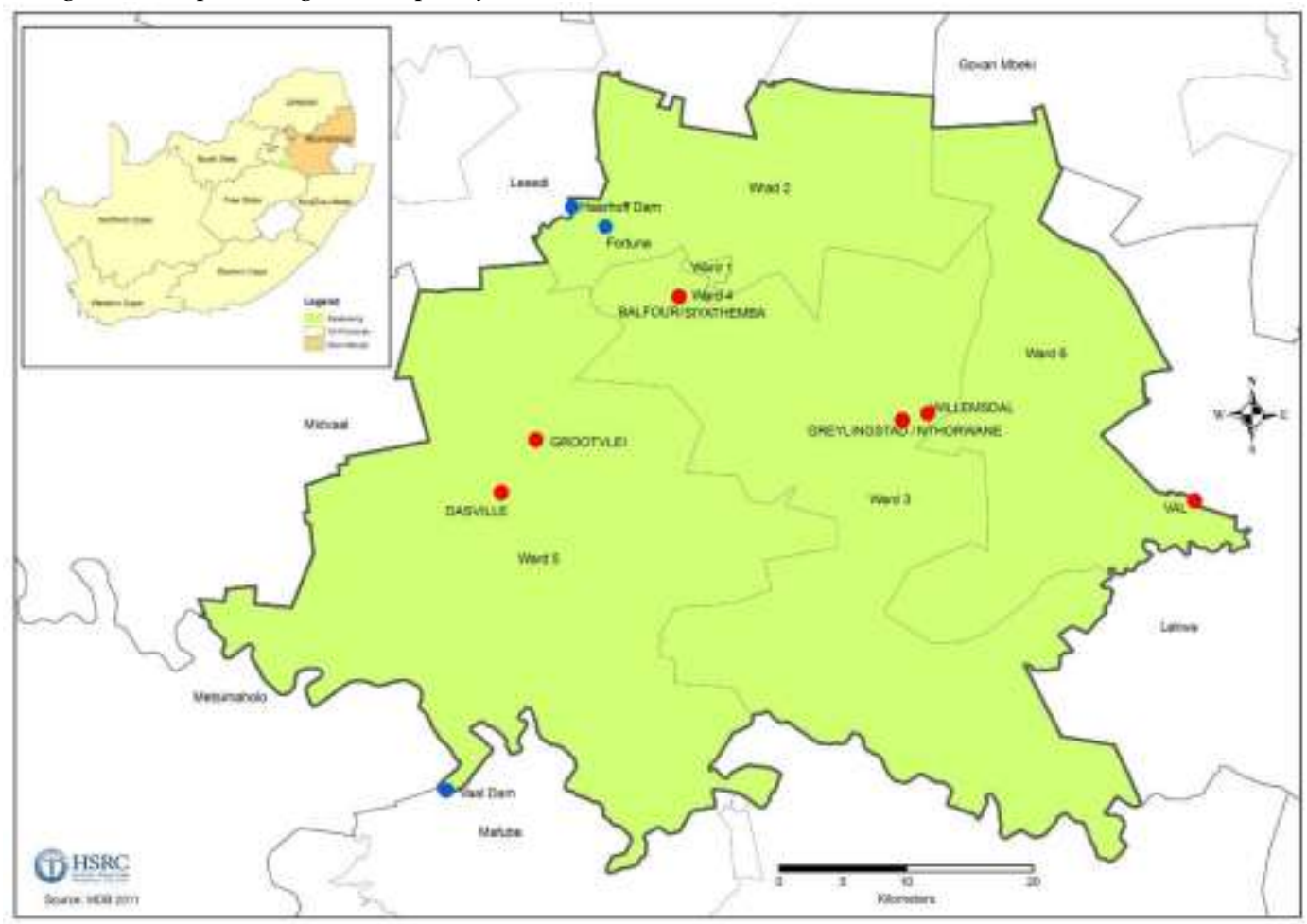

\section{Socio- economic characteristics}

The socio-economic conditions of each municipality can be measured, by poverty rate, unemployment, and gross geographic product $\left(\mathrm{GGP}^{59}\right)$. Figure 4 below shows the decline in the poverty rate from $69.31 \%$ in 2001 to $60.93 \%$ in $2004^{60}$, which could be attributed to government

\footnotetext{
${ }^{59}$ The Gross Geographic Product (GGP) is a measure used in South Africa to assess the total and sectorial economic activity on an annual basis within municipalities

60 "Poverty income is defined as the minimum income needed to sustain a household and varies according to the size of the household. For example, the monthly poverty income in 2009 for a household of four.... was R2, 440 and R3,396 for a
} 
spending on expanded public works programmes (EPWP), and other nationally and provincially driven programmes aimed at poverty reduction. Monitoring poverty levels shows the slow decline in poverty rate from 60.93\% in 2004 to 59.75\% in 2006 (Poverty Database, HSRC, 2006).

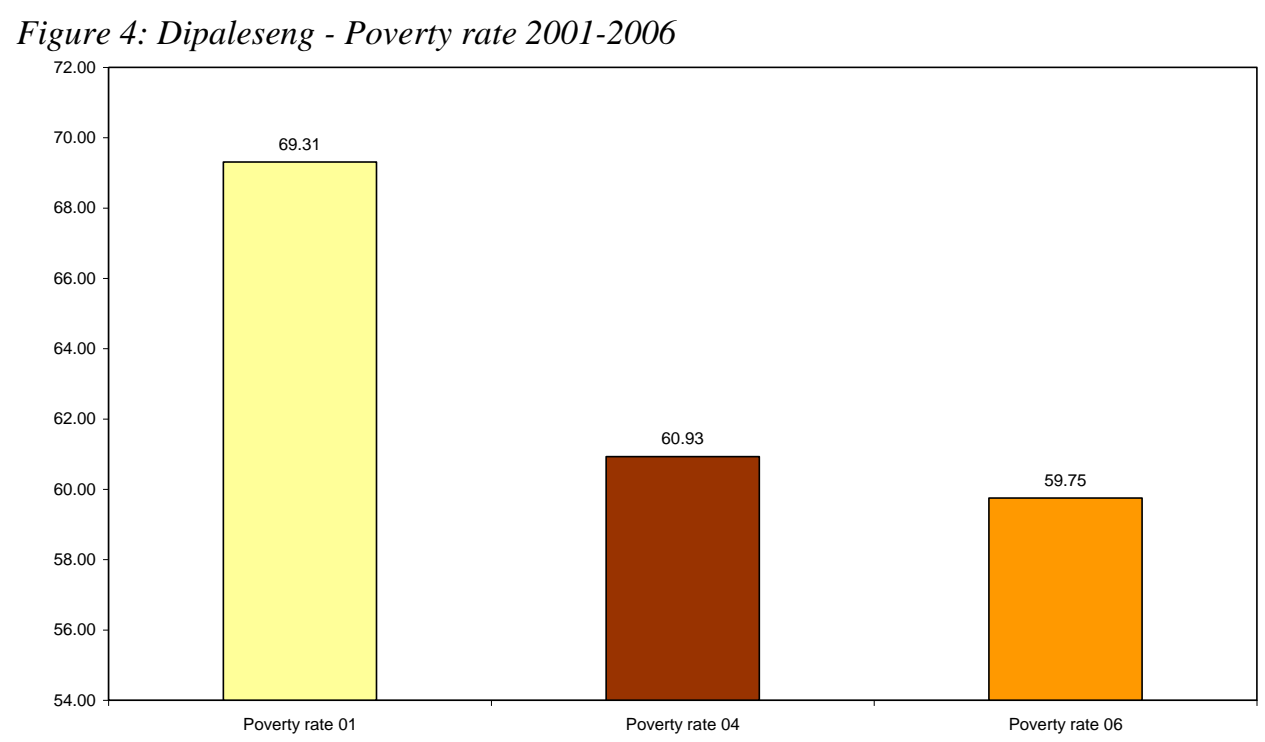

To explore the reasons attributed to the rise/decline of poverty it is important to understand the economy of the municipality, and key economic sectors. Mpumalanga as a whole is known for production of maize, sunflower, groundnuts, citrus fruits etc. Dipaleseng contributes $3.48 \%$ to Mpumalanga's agricultural income. In 2001 agriculture, community services and trade were the top three sectors, with agriculture contributing $21 \%$ to the municipality's total GDP (Figure 5).

In addition crop production, livestock, dairy farming and commercial logging are also prevalent in the whole of Mpumalanga; Dipaleseng also plays a role in this sub-sector hence the existence of the biggest abattoir (Karan Beef) that employs largely Dipaleseng residents.

Dipaleseng experienced a severe decline in agricultural income between 2001-2004. Even today it has failed to recover fully. From 2004-06 some improvement was seen which can be attributed to LED programme, although the economy did not reach the 2001 mark (Figure 6). Dipaleseng has a number of small-scale agricultural projects (Dipaleseng IDP2008/09) which include: Mphatlalatsane Cooking Oil; Siyafuya Piggeries; Rainbow Nation Piggery; Harambee (farming) and Sinqobile (wood). 
Figure 5: Dipaleseng GGP by sector 2001

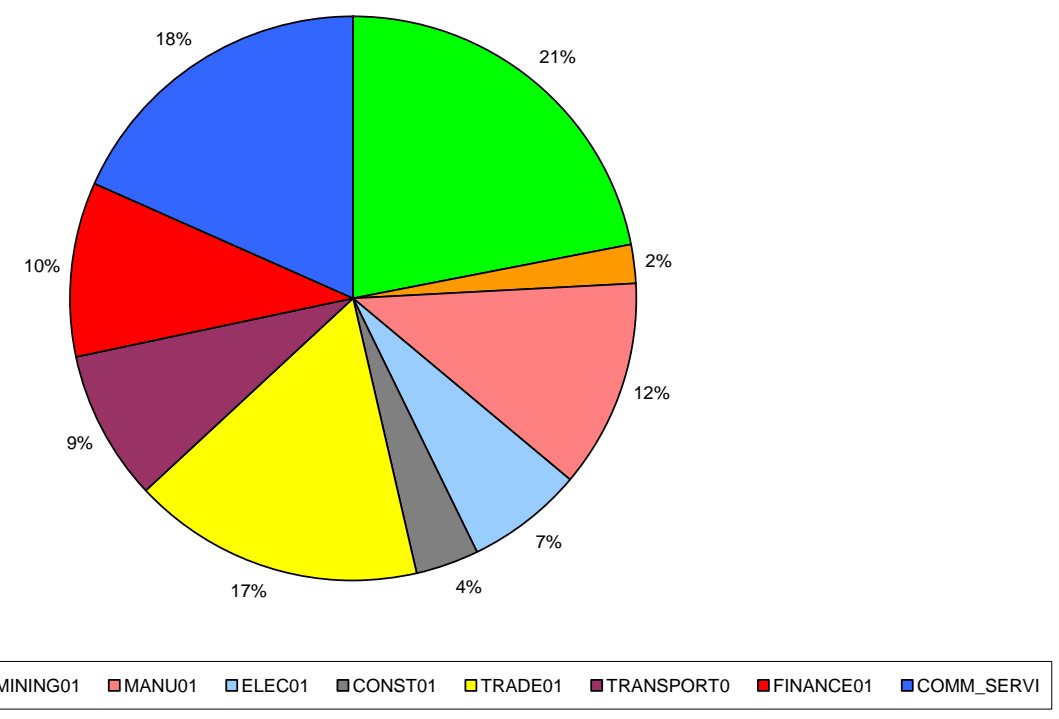

Figure 6: GGP-Agricultural Sector 2001-2006

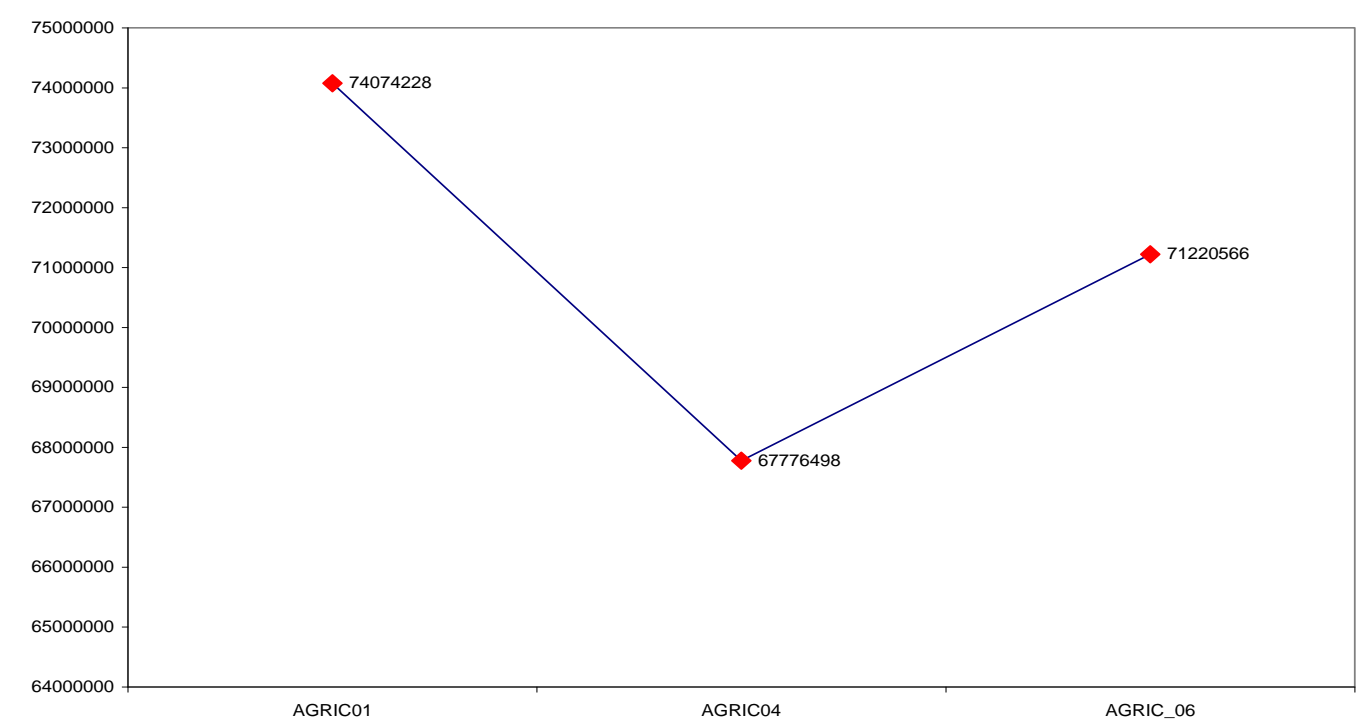

The total GGP (all sectors combined) however shows a positive change within the same period (Figure 7). This positive change may be attributed to the growth in the secondary sectors e.g. manufacturing, trade, finance and community services. With the exception of manufacturing the other three sectors were stable from 2001-2004 despite the decline in agriculture (-R 6,297,730) and mining (- R404, 332) in this municipality (Economic database, HSRC, 2006). 
Figure 7: Dipaleseng Total GGP 2001-2006

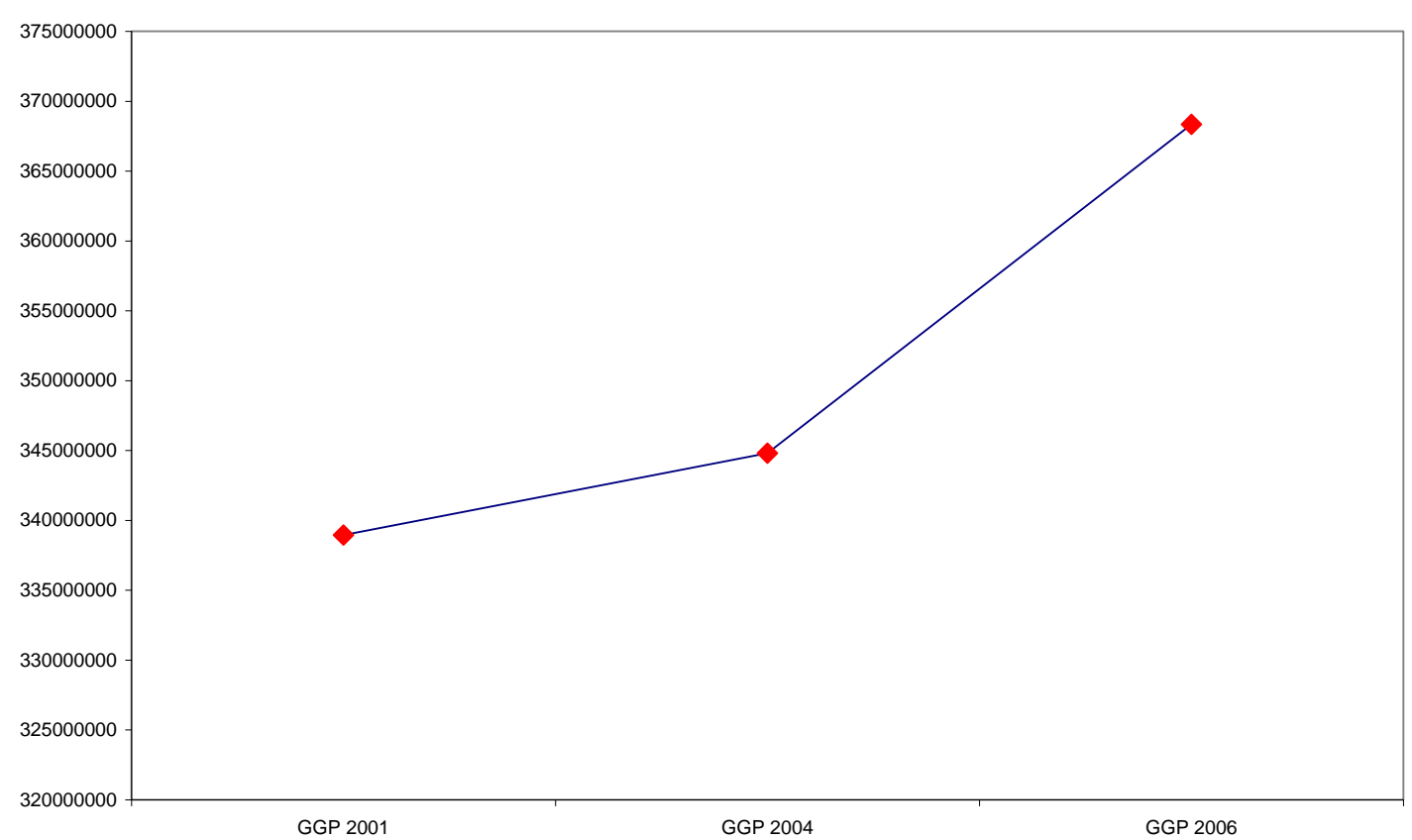

\section{Provision of basic services}

Key to the adequate provision of services is the understanding of the demographic characteristics of the population within the municipality. The total population for Dipaleseng was estimated at 38,726 in 2009 (SA mid-year estimates 2009 cited in GSDM 2010/11 IDP). Planning for services needs to be forecast, and estimating the population growth rate is crucial for medium to long-tern planning. This will assist the municipality in developing plans and budgets based on the forecast demand for their services. According to the GSDM, the growth rates from 2005 to 2010 are as follows:

\begin{tabular}{|c|c|}
\hline Ward $1=3 \%$ & Ward $4=3 \%$ \\
\hline Ward $2=2.5 \%$ & Ward $5=1.5 \%$ \\
\hline Ward $3=1.5 \%$ & Ward $6=$ \\
\hline
\end{tabular}

Failure to meet the demand for basic services results in unhealthy, unsafe and hazardous habitats which leads to diseases, disasters etc. The services may either be lacking, inadequate or of a lower standard. That is why it is crucial to understand the level/standard at which the services are provided (Figure 8)

Figure 8: Service levels

\begin{tabular}{|l|l|l|l|}
\hline Service type & Level 1 Basic & Level 2 Intermediate & Level 3 Full service \\
\hline Water & Communal standpipes & Yard taps, yard tanks & In house water \\
\hline Sanitation & Sewage collection/disposal & VIP latrine/septic tanks & Full water borne \\
\hline Electricity & 5-8 Amp/non-grid electricity & 20 Amps & 60 Amps \\
\hline Roads & Graded & Gravel & $\begin{array}{l}\text { Paved/tarred \& } \\
\text { kerbs }\end{array}$ \\
\hline Storm water drainage & Earth lined open channel & Open channel lined & Piped system \\
\hline Solid waste disposal & Communal (residents) & Communal (contractor) & Kerbside \\
\hline \\
Source: ETU (n.d.)
\end{tabular}




\section{Housing}

Housing is not the responsibility of the municipality but that of the provincial Department of Human Settlements, but is also considered in this paper as it was also part of local grievances. Some $43 \%$ of the households in Dipaleseng are informal (backyard and free standing shacks). This shows an increase of $9 \%$ from the 2001 census data which recorded $34 \%$ households living in shacks. $43 \%$ is a huge percentage. Figure 9 shows the varying backlog between rural and urban areas.

Figure 9: Status Quo for housing
\begin{tabular}{|l|l|l|}
\hline PROGRAMME & PLANNED TARGETS & $\begin{array}{l}\text { REMARKS /COMMENTS ON } \\
\text { ACHIEVEMENT }\end{array}$ \\
\hline In Situ Development Ext 5 & $\begin{array}{l}\text { Provision and complete the } \\
\text { project for } 236 \text { units }\end{array}$ & $\begin{array}{l}\text { Progress not satisfactory and } \\
\text { quality is compromised }\end{array}$ \\
\hline 100 Housing units for Ward 284 & Eradication of all in-situ shacks & $\begin{array}{l}\text { More allocation required from } \\
\text { Dept of Human Settlement }\end{array}$ \\
\hline $\begin{array}{l}100 \text { Housing units distributed } \\
\text { amongst W:3=30, W: } 1=20, \\
\text { W:5 } 50, \text { and W: } 30 \text { [in situ dev.] }\end{array}$ & $\begin{array}{l}\text { To eradicate } 2034 \text { units backlogs } \\
\text { in all in situ settlements. }\end{array}$ & $\begin{array}{l}\text { Backiogs escalating whereas } \\
\text { allocation diminishes }\end{array}$ \\
\hline $\begin{array}{l}\text { Grootvlei informal settlements } \\
1000 \text { units [in situ dev.] }\end{array}$ & $\begin{array}{l}\text { To reduce this by } 75 \% \text { before the } \\
\text { end of } 2011 / 12 \text { F/Y. }\end{array}$ & $\begin{array}{l}\text { Solicit allocation from Dept of } \\
\text { Human settlements }\end{array}$ \\
\hline $\begin{array}{l}\text { Siyathemba Ext } 7,750 \text { units } \\
\text { including Ext } 2 \text { South portion [in } \\
\text { situ dev] }\end{array}$ & $\begin{array}{l}750 \text { units to be built before the } \\
\text { end of } 2011 / 12 \text { financial year }\end{array}$ & $\begin{array}{l}\text { Dept of Human settlements to } \\
\text { fast track allocation for this in situ } \\
\text { development }\end{array}$ \\
\hline
\end{tabular}

Source: Gert Sibande DM IDP 2010/11 Situation 3

\section{Water and sanitation}

According to the Community Household Survey findings of 2007, 48.6\% of households in Dipaleseng have water inside the dwelling, 32.9\% within the yard and $14 \%$ use communal taps outside the yards (Community Survey, Stats SA 2007). The municipality has made some strides in terms of water provision compared to 2001 . In 2001 only $20 \%$ of households had a water supply in the dwelling, $56.4 \%$ in the yard, $17 \%$ were relying on communal taps and $6.3 \%$ used other sources. In rural areas households mainly rely on other sources of water - boreholes, springs, or dams - due to the lack of water supply networks in these settlements. Dipaleseng relies on one pressure tower, which distributes water from the Vaal and Haarhoff dams to five reservoirs.

Among the complaints that the people vented was the lack of water and its poor quality. According to the municipality there is only one purification plant that is situated in Fortuna. Dipaleseng relies on it but the engineers had long warned that it was fast nearing its capacity (Dipaleseng IDP, 2008/09).

In 2001 only $38.7 \%$ had access to a flush toilet connected to sewer. The 2007 data from the Community Survey shows that $68.1 \%$ have flush toilet. This is a remarkable improvement from $29.4 \%$. In an attempt to even do better the municipality has provided new townships with long-drop toilets, meeting an intermediate standard in an effort to eradicate the bucket system of sewage disposal (a basic or level 1 standard). About $4.3 \%$ households were still using the bucket system in 2007 compared to $19.1 \%$ in 2001 . In rural areas each household is responsible for sanitation so many 
use pit latrines or having no facility. According to the IDP 2008/09 four major sanitation projects were prioritized. These were:

- Sewer reticulation and maintenance in Siyathemba to benefit Wards $2 \& 4$

- Completion of sewer pump station in Nthorwane to benefit Ward 6

- Completion of sewer reticulation in Balfour to benefit Ward 3

According to Statistics SA Community Survey, $16.5 \%$ households had no toilets in 2007 but recently only $3.6 \%$ households are reported to have no access to any form of sanitation. Figure 10 shows current access to toilets by type between key areas.

Figure 10: Sanitation type by nodal towns

\begin{tabular}{|l|c|c|c|c|c|}
\hline Category & Balfour & Siyathemba & Greylingstad & Nthorwane & Grootvlei \\
\hline $\begin{array}{l}\text { Flush toilet } \\
\text { [connected to } \\
\text { sewerage } \\
\text { system] }\end{array}$ & 1800 & 6300 & 0 & 1400 & 1100 \\
\hline $\begin{array}{l}\text { Flush toilet [with } \\
\text { septic tank] }\end{array}$ & 200 & 0 & 1000 & 0 & 0 \\
\hline Dry toilet facility & 500 & 1500 & 300 & 1000 & 600 \\
\hline
\end{tabular}

Source: Gert Sibande DM IDP 2010/11 Situation 3

\section{Electricity supply}

In terms of energy source for lighting most households use electricity (78.5\%) and the rest rely on other sources e.g. candles, paraffin etc. In 2001, 65.5\% households had electricity and the backlog was about 32\%. By 2007 the backlog was about $21 \%$. The municipality then prioritized a project on Massive Electrification of Households, worth R6m, to be funded by the Department of Minerals and Energy, which would benefit all the wards within Dipaleseng.

\section{Refuse removal}

Some $77.3 \%$ of households have access to refuse removal by local council once a week, an improvement of $11.8 \%$ from 2001. The municipality had a backlog of $22.6 \%$ in 2007 (Stats SA, 2007). The municipality has only three solid waste disposal sites in Balfour and Grootvlei. The communities in rural areas use own disposal methods (i.e. burning, pit dumps etc). The challenge that the municipality faces include financial resources, inadequate equipment and unregistered landfill sites. 


\section{Protests in Dipaleseng}

In 2009 a wave of protest swept the country; there was concern that service delivery demonstrations would degenerate into xenophobia, but there was a history of opposition to xenophobia in Siyathemba, Balfour's township. The Sowetan reported:

The community submitted a memorandum to the Dipaleseng Municipality on 8 July 2009. Most demands concerned basic issues such as a request for a police station, a mini-hospital and high-mass lights. Topping the list were calls for a skills training centre and policies governing job recruitment in the area.

These reflect the fact that while the protest was backed by the community, leadership was provided by the township's youth. It is this generation that suffers most from unemployment and lack of housing. Moreover, many of the older leaders are now politicians and tenderseekers.

The council failed to respond to the July 8 memorandum, hence the 19 July meeting [was called and] voted for a stay away. Some activists suspect that police violence was aimed at intimidating them. It had the reverse effect. People fought back and the stay-away lasted four days (Sowetan 2009).

The police fired rubber bullets and teargas as people left the meeting, and protestors set fire to two buildings and shops were looted (Sowetan, 2009). Clearly feelings were running high on both sides.

In analysing the community demands of 8 July (Appendix 1), it is important to assess:

- how they fit into the services provided by the municipality

- are communities aware of who does what between the spheres of government?

- are they using appropriate channels to voice their dissatisfaction and, if not, how can this be remedied?

- is violent protest justified?

In the community's memorandum of 8 July 2009, half of the demands fell out of the jurisdiction of the municipality. Communities often see municipalities as their channel to reach provincial and national government, which makes the municipality the target of misdirected anger and frustrations by the citizens. This could be addressed through public participation methods (i.e. ward committee meetings, imbizos etc) to explain the following:

- different roles and responsibilities of the three spheres of government

- rights and responsibilities of the citizens

- channels for redress

- the municipality's achievements with regard to the IDPs and other development initiatives.

The municipality has improved in a number of areas as outlined above but has to increase the pace of service-improvement to communities that need them most. To prevent similar protests in the future the municipalities need to strengthen its communication with the residents. It has to inform them of its achievements and also delays/bottlenecks regarding the provision of services. 
While the need for communities to voice their dissatisfaction with services is justified as it forms part of the democracy the South Africans voted for, the violence coupled with the protests harms interests on both sides.

\title{
Way to the future for Dipaleseng
}

After the protests a high profile delegation which included President Zuma visited the communities and a task team was appointed to look into the grievances outlined in the memorandum. By February 2010, more protests occurred as citizens, particularly the youth, saw government as being unresponsive to their grievances as nothing visible was happening in terms the concerns raised in July 2009.

In May 2011 the Acting Minister of CoGTA, Mr Nathi Mthethwa, received the report back from the task team. In his response to the report he stated:

\begin{abstract}
In line with the local Government Turn Around Strategy (LGTAS) that the Cabinet adopted in December 2009 as well as the Municipal Turnaround Strategies (MTAS) developed per municipality, the lives of the people of Dipaleseng are fast getting turned around for the better! The reality of a better life gets closer with every coordinated effort between government and local communities. (Acting Minister, CoGTA May 2011)
\end{abstract}

Visible improvements could be seen in programmes addressing: roads and storm water drainage; water and sanitation; housing; electricity; public amenities; social and economic development; education and skills development; and public/private partnerships.

\section{Private sector}

The role of the private sector in supporting development is interesting. The Burnstone Gold mine which is under Great Basin Gold International Mine has employed 108 people from Siyathemba Township and other neighboring towns (Mining Weekly, 9 February 2010). Burnstone Gold already had various initiatives in place prior to the protests, although the residents still perceived the mine as employing people from outside the municipality. The Great Basin Gold company entered into a MoU with Mpumalanga Development Agency, among other things promising to:

- Develop the economy of Mpumalanga Province and Dipaleseng Municipality, and

- Unlock the economic development potential of Dipaleseng Local Municipality (DLM) by:

- Working closely with the Municipality for the revitalisation of the economy of settlements within Dipaleseng Municipality;

- Promoting business-to-business linkages, with the intention of promoting local Small Medium Enterprises' growth therefore tackling the problems of unemployment and social exclusions

- Providing financial and non-financial assistance to potential investors and local small and medium enterprises, specifically supporting Great Basin Gold's endeavour to provide business support to local existing and emerging enterprises 
- Create a culture of long term sustainable vision to ensure that the growth and development programs established under the MoU uphold the principle of sustainable development. Currently the mine is supporting at least eight local enterprises: a laundry, cleaning, gardening, waste collection, construction, catering, sunflower farming and an employee shuttle service;

- Provide an avenue for coordination of economic development initiatives to enhance the activities of the Dipaleseng Development Programme, implemented in partnership with the Municipality. The program was established to integrate the mine employees' housing needs into the municipality's current housing and economic development initiatives; and

- Strengthen cooperative and government/private sector relations. Great Basin Gold has already provided capacity building to the Dipaleseng Local Municipality by seconding a Project Manager to establish a project management unit and assist the municipality to access infrastructure funding.

\section{Questions}

Various questions remain unanswered as a result of the protest. Does this mean that protesting is the language that government understands most? Do communities need to protest before service delivery is speeded up? What about the non-protesting communities elsewhere? Are they going to be denied their right to basic services? Does protesting and non-protesting mean dissatisfaction and satisfaction with the services?

One solution which has been successful in communicating people's needs is the Citizen Report Card which is a tool to strengthen public-government communication (Zama 2012). The CRC is can be used across all levels of government to provide feedback from citizens regarding:

- Availability, reliability and quality of services

- Access to and satisfaction with services

- Responsiveness of service provider

- Willingness to pay

- Hidden costs ( corruption \& support system), and

- Quality of life

Feedback is then disseminated through various media where after dialogues between citizens and departments for services are conducted. The end product is a social compact which is the contract between citizens (recipients of services) and government (service provider). Depending on the agreement between citizens and the municipality CRC can be repeated every 2-5 years. This will enhance the public officials' performance and improved efficient, effective and quality service delivery. 


\section{References}

Dipaleseng Municipality (2008) Integrated Development Plans 2008/09

Dipaleseng Municipality (2009) Water Services Development Plan 2009-2013

ETU (n.d): Local Government in South Africa Municipal Service Delivery [Online] Education \& Training Unit (ETU) www.etu.org.za/toolbox/docs/localgov/muniservice.html, accessed 04/11/2010

Gert Sibande DM (2010) Integrated Development Plans 2010/2011 Part 3

Great Basin Gold (2009) Great Basin Gold together with Mpumalanga Economic Growth Agency signs a MOU.... [Online] Available from http://www.grtbasin.com/index.html/p 99, accessed: 27/03/2009

Jain, H. (2010). Community Protests in South Africa: Trends Analysis and Explanations in Local Government working paper series No. 1. [Online] Available from http://www.ldphs.org.za/publications/publications-bytheme/local-government-in-south-africa/community-protests/FinalReport/.pdf/view, accessed 10/11/13

Mining Weekly (2010) Great Basin Gold says Burnstone mine employs local workers. $2^{\text {nd }}$ February. [Online] Available from http://www.miningweekly.com/article/great-basin-says-burnstone-mine-employs-local-workers2010-02-09, accessed: 22/06/2011

Mpumalanga Province (2011) Mpumalanga Economic Growth \& Development Path “Towards a more equitable and inclusive economy” October 2011, http://www.mpumalanga.gov.za/dedet/MEGDP.pdf, accessed $10 / 11 / 2013$

Sowetan, (2009) It's not xenophobia, Abahali baseMjondolo Shackdwellers Movement South Africa http://abahlali.org/node/5549, accessed 10/11/2012

Statistics SA (2007) Community Survey [Online] Available from http://www.statssa.gov.za/community_new/content.asplink=interactivedata.asp, accessed 01/11/2010

Zama, SB. (2012) Citizen Report Card Surveys: A tool for effective social accountability, Human Sciences Research Council, Policy Brief, www.hsrc.ac.za/en/research-data/view/5878, accessed 10/11/2013 


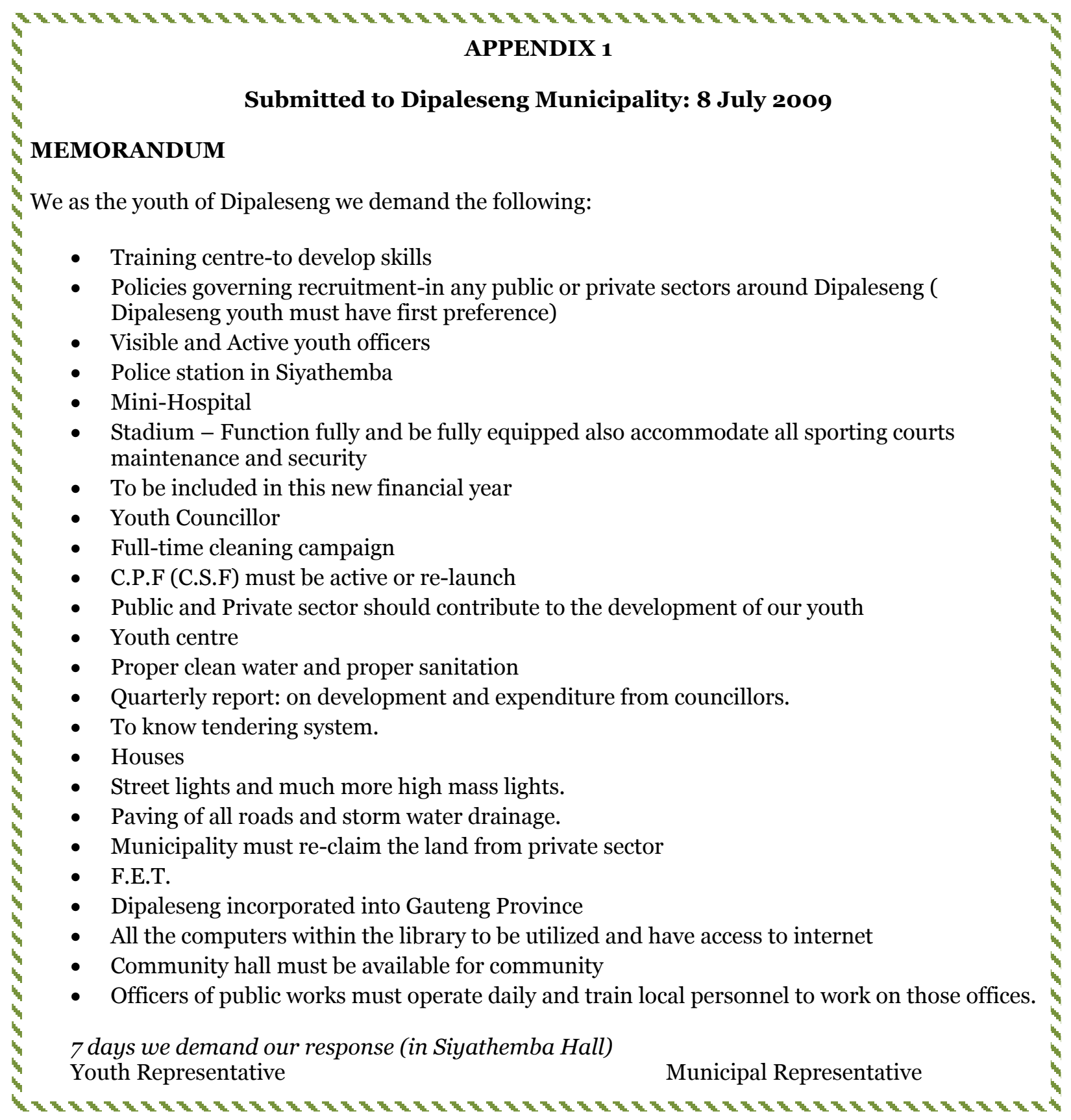

